\title{
A review of HELLP syndrome, in 17 patients
}

\author{
Davut Güven $^{1}$, Kadir Bakay ${ }^{2 *}$, İdris Koçak ${ }^{1}$, Cazip Üstün ${ }^{1}$ \\ ${ }^{1}$ Department of Obstetrics and Gynecology, 19 Mayis University School of Medicine, Samsun, Turkey \\ ${ }^{2}$ Private Hospital Department of Obstetrics and Gynecology, Turkey \\ Email: * drkadirbakay@gmail.com
}

Received 15 May 2012; revised 27 June 2012; accepted 9 July 2012

\begin{abstract}
Introduction: Preeclampsia is a well known obstetric complication characterized with hypertension and proteinuria whereas HELLP syndrome (hemolysis, elevated liver enzymes, low platelet count) which was first stated by Prichard in 1954 and described by Weinstein in 1982, is a multisystemic disease usually seen in the third trimester and in the postpartum period, usually in 48 - 72 hours following delivery [1]. Aim: In this study we aim to share our experience in 17 patients with HELLP syndrome treated in our clinic between January 2005 and March 2008 in regard of the current literature. Material and Methods: 17 patients diagnosed with HELLP syndrome between January 2005 and March 2008 were retrospectively re-evaluated in regard of symptoms, treatment options and prognosis. As such this is a retrospective study focusing on case reports. Conclusion: As noted before main focus of treatment should be on patient stability, in other words, palliative care under intensive care conditions.
\end{abstract}

Keywords: HELLP; Preeclampsia; Eclampsia; 17 Patients

\section{INTRODUCTION}

Preeclampsia (eclampsia; Greek, "shining forth") is a well known obstetric complication characterized with hypertension and proteinuria whereas HELLP syndrome (hemolysis, elevated liver enzymes, low platelet count) which was first stated by Prichard in 1954 and described by Weinstein in 1982, is a multisystemic disease usually seen in the third trimester and in the postpartum period, usually in 48 - 72 hours following delivery [1].

With an incidence of $0.2 \%-0.8 \%$ in all pregnancies and $10 \%$ in severe pregnancy its etiology and pathogenesis is still not fully revealed though it is assumed genetic inheritance, abnormal placentation, immunologic factors and maternal vasculo endothelial dysfunction may play a

${ }^{*}$ Corresponding author. role [2].

These factors may cause segmental vasospasms and endothelial lesions causing fibrine deposits that result in micro circulatory dysfunctions [3].

Changes described in HELLP syndrome can adversely affect liver and renal functions causing elevated liver enzymes and proteinuria [4].

There are various complications known to be associated with HELLP syndrome, including but not limited to; ascites, pleural effusion, pulmonary edema and disseminated intravascular coagulation (DIC) $[1,5,6]$.

In this study we aim to share our experience in $17 \mathrm{pa}-$ tients with HELLP syndrome that were treated in our clinic between January 2005 and March 2008 in regard of the current literature.

Of the 17 cases we have thus reviewed, 3 required intensive care management, the remaining 14 recovered in 24 hours after delivery without any complications hence were monitored in the obstetric clinic.

\section{AIM}

In this study we aim to share our clinical experience in 17 patients with HELLP syndrome treated in our clinic between January 2005 and March 2008 in regard of the current literature. We especially aim to present 3 cases who were treated in the intensive care unit to remark treatment options and prognosis in such extreme conditions.

\section{MATERIAL AND METHODS}

17 patients diagnosed with HELLP syndrome between January 2005 and March 2008 were retrospectively reevaluated in regard of symptoms, treatment options and prognosis. As such this is a retrospective study focusing on case reports. Patients who were treated in intensive care unit are presented in detail as an example of how far the disease could progress and how dramatically it can fully resolve if managed right.

\subsection{Case 1}

A 25 years old 35 weeks twin pregnancy patient admitted 
to our clinic complaining of headache and nausea. Upon initial examination blood pressure was $170 / 120 \mathrm{mmHg}$ with ascites and remarkable pretibial edema. In pelvic examination cervix was firm and closed. Ultrasonography showed two viable fetuses. Initial laboratory results were as follows; $\mathrm{Hb}: 9.8 \mathrm{~g} / \mathrm{dl}$, Hct: $32.9 \%$, Platelets: 177.000, SGOT: 42 IU/1, SGPT: 48 IU/1, proteinuria was present and coagulation parameters were in normal range.

Immediate caesarean section was performed and two viable fetuses were delivered.

2 hours following delivery a second laparotomy was deemed necessary due to uncontrollable vaginal bleeding. An increase in liver enzymes and a severe drop in platelet count were observed right after operation with SGOT: 66 IU/1, SGPT: $81 \mathrm{IU} / 1$ and 89.000 respectively.

With the appearence of tonic-clonic seizures and severe breathing irregularity along with persistant high blood pressure, patient was intubated and transferred to the intensive care unit.

While undergoing palliative therapy and close monitoring a one session of hemodialysis was needed because of anuria and edema. Blood transfusion and fresh frozen plasma had to be administered to stabilize hemodynamic parameters and vascular stability.

With the return of renal functions, viable vital signs and normal laboratory results patient was extubated on the 3rd day in intensive care unit. During follow-up no other complications were observed and the patient was discharged 10 days after operation.

\subsection{Case 2}

A 31 years old 20 weeks pregnancy diagnosed with preeclampsia was brought to our clinic after having suffered a tonic-clonic seizure at home. Upon initial examination patient was comatose with a Glascow Coma Score of 9 and blood pressure was 140/90 $\mathrm{mmHg}$, fetal cardiac activity was absent. Laboratory results were as follows; $\mathrm{Hb}$ : 10.9 g/dl, Hct: 34 \%, Platelets: 73.000, SGOT: 81 IU/1, SGPT: 67 IU/1 and coagulation parameters were in normal range.

Immediate caesarean section was performed and the patient transferred to the intensive care unit right after the operation without extubation.

$\mathrm{MgSO}_{4}$ therapy was initiated closely monitoring magnesium levels and urinary output along with replacement therapy. Hemodialysis was required after stopping $\mathrm{MgSO}_{4}$ due to anuria and edema albeit normal magnesium levels.

After having been intubated for 4 days in the intensive care unit, with continuous monitoring and replacement therapy renal functions returned to normal and liver enzymes were in a normal range. Patient was transferred back to our clinic after 7 days in the intensive care unit and discharged on the 10th day after operation without any further complications.

\subsection{Case 3}

A 24 years old 33 weeks pregnancy with a previous history of caesarean section and diagnosed with preeclampsia admitted to our clinic complaining of pelvic pain and contractions. Upon initial examination blood pressure was $150 / 110 \mathrm{mmHg}$ pretibial edema was present. In pelvic examination cervix was dilated $3 \mathrm{~cm}$ with an effacement of $70 \%$ indicating active labor. Ultrasonography showed one viable fetus. Initial laboratory results were as follows; $\mathrm{Hb}$ : $12.8 \mathrm{~g} / \mathrm{dl}$, Hct: 36\%, Platelets: 141.000, SGOT: 32 IU/1, SGPT: 37 IU/1, proteinuria was present and coagulation parameters were in normal range.

Immediate caesarean section was performed and a single viable fetus was delivered.

After a rise in blood pressure and liver enzymes along with a decrease in platelet count in the post operative 8th hour, patient was transferred to the intensive care unit for close monitorization. Patient's renal functions were normal and with palliative therapy vital signs and laboratory results returned to normal range. Patient was transferred back to our clinic after 3 days in the intensive care unit and discharged on the 8th day after operation without any further complications.

\section{DISCUSSION}

HELLP syndrome is diagnosed with hemolysis, elevated liver enzymes and low platelets first stated by Prichard in 1954 and described by Dr. Louis Weinstein in 1982 [1].

In current literature HELLP syndrome is described as a complication usually seen in the early post partum period, up to 6 days, most frequently in the first 48 hours [7].

Of the 3 cases we discussed above, 2 had acute renal failure requiring hemodialysis. Acute renal failure in HELLP syndrome is a very serious complication with an incidence of $7.3 \%$ as stated by Sibai [8].

Endothelial damage, vasospasm, platelet activation and a decrease in endothelium derived relaxing factor activity may be blamed for acute renal failure in HELLP syndrome [9].

Whatever the cause, acute renal failure in HELLP syndrome is a serious condition which requires early intervention and intensive care management. Also patients with HELLP syndrome and acute renal failure are more susceptible to other severe complications such as multi organ failure including lungs, brain and heart.

Hemolysis in HELLP syndrome can lead to DIC if left unattended therefore it is fairly important to intervene early if such a condition arises. There is no decisive marker to foretell if hemolysis will occur in a preeclamp- 
tic patient but a review of current literature shows Haptoglobin to be the most sensitive parameter [10].

Even after numerous studies there is still debate on the diagnosis and treatment of HELLP syndrome [11,12]. Main focus should be on palliative care and replacement therapy but as shown in our study hemodialysis might be necessary if renal failure is observed.

It is debatable whether or not to administer platelet transfusion to patients with low platelet count to prevent hemorrhage. But transfusion is recommended to patients prior to labor if their platelet count is below 50.000 [13].

Rahman et al. administered steroids to patients with 24 - 34 weeks of pregnancy to further fetal maturation and they observed that when used on patients with HELLP syndrome their platelet count showed a tendency to rise [13].

Also Martin et al. suggested that dexamethasone might benefit patients with a postpartum onset HELLP syndrome [14].

\section{CONCLUSIONS}

As noted before main focus of treatment should be on patient stability, in other words, palliative care under intensive care conditions.

But more importantly all patients with preeclampsia should be closely monitored both in the antepartum and postpartum period. Awareness in these patients is what saves lives.

\section{REFERENCES}

[1] Weinstein, L. (1982) Syndrome of hemolysis, elevated liver enzymes, and low platelet count: A severe consequence of hypertension in pregnancy. American Journal of Obstetrics \& Gynecology, 142, 159-167.

[2] Sezik, M., Özkaya, M.O., Sezik, H.T., Yapar, E. and Kaya, H. (2005) HELLP sendromlu hastalarda umblikal arter doppler incelemesinin perinatal sonuçlarla ilişkisi. Perinatoloji Dergisi, 13, 198-202.

[3] Loos/Rath (1992) Das HELLP-syndrom-ein "gestaltwandel der praeklampsie”. Geburtsh. u. Frauenheilk, 52, 581-585.

[4] Keleş, G.T., Topçu, İ., Kefi, A., Ekinci, Z. and Sakarya, M. (2006) Yoğun bakım ünitesinde obstetrik olgular. Firat
Tıp Dergisi, 11, 62-65.

[5] Weinstein, L. (1985) Preeclampsi/eclampsi with hemolysis, ele vated liver enzymes and trombocytopenia. Obstetrics \& Gynecology, 66, 657.

[6] Sibai, B.M., Taslimi, M.M., EL-Nazer, A., Aman, E., Mabie, B.C. and Ryan, G.M. (1986) Maternal-perinatal outcome associated with the syndrome of hemolysis, elevated liver enzymes, and low platelets in severe preeclampsia, eclampsia. American Journal of Obstetrics \& Gynecology, 155, 501-509.

[7] Tsoe, E., Reid, R.P., Barish, R.A. and Browne, B.J. (1987) Late past partum eclampsia. Annals of Emergency Medicine, 16, 907-909. doi:10.1016/S0196-0644(87)80533-4

[8] Sibai, B.M. and Ramadan, K.M. (1993) Acute renal failure in pregnancies comp licated by hemolysis, elevated liver enzymes, ad low platelets. American Journal of Obstetrics \& Gynecology, 168, 1682-1690.

[9] Sibai, B.M., Villar, M.A. and Mabie, B.C. (1990) Acute renal failure in hypertensi ve disorders: Pregnancy outcome and remote prognosis in thirty-one consecutive cases. American Journal of Obstetrics \& Gynecology, 162, 777-783.

[10] Kuhn, W., Rath, W., Loos, W. and Graeff, H. (1992) Le syndrome hellp. Resultats cliniques et d'analyse en laboratoire. Rev Fr Gynecol Obstet, 87, 323.

[11] Sibai, B.M. (2004) Diagnosis, controversies, and management of the syndrome of hemolysis, elevated liver enzymes, and low platelet count. Obstetrics \& Gynecology, 103, 981-991. doi:10.1097/01.AOG.0000126245.35811.2a

[12] Haddad, B., Barton, J.R., Livingston, J.C., Chahine, R. and Sibai, B.M. (2000) HELLP (hemolysis, elevated liver enzymes, and low platelet count) syndrome versus severe preeclampsia: Onset at $<$ or $=28.0$ weeks' gestation. American Journal of Obstetrics \& Gynecology, 183, 14751479. doi: $10.1067 / \mathrm{mob} .2000 .106975$

[13] Rahman, T.M. and Wendan, J. (2002) Severe hepatic dysfunction in pregnancy. An International Journal of Medicine, 95, 343-357.

[14] Martin, J.N. Jr, Perry, K.G. Jr, Blake, P.G., May, W.A., Moore, A. and Robinette, L. (1997) Beter maternal outcomes are achieved with dexamethasone therapy for postpartum HELLP (hemolysis, elevated liver enzymes and trombocytopenia) syndrome. American Journal of Obstetrics \& Gynecology, 177, 1011-1017. doi:10.1016/S0002-9378(97)70005-X

\section{ABBREVIATIONS}

HELLP: hemolysis, elevated liver enzymes, low platelet count;

DIC: disseminated intravascular coagulation;

$\mathbf{M g S O}_{4}$ : magnesium sulphate. 